Arabiyat : Jurnal Pendidikan Bahasa Arab dan Kebahasaaraban

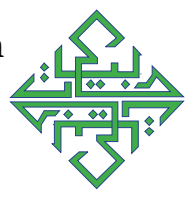

\title{
RECRUITMENT MANAGEMENT FOR MEMBERS OF ARABIC LEARNING IN ARABIC LANGUAGE STUDENT ASSOCIATION
}

\author{
Muhamad Rizal Falaqi, Ahmad Fahmi Arif Ahda, Danial Hilmi \\ Universitas Islam Negeri Maulana Malik Ibrahim Malang, Indonesia \\ Jl. Gajayana No. 50, Kec. Lowokwaru, Kota Malang, Jawa Timur, 65144, Indonesia \\ Corresponding E-mail:falaqirizal@gmail.com
}

\begin{abstract}
We steered this research to explore the recruitment and selection management of members based on interests applied by the selection team in the Arabic language student association. This research was a case study with a qualitative approach. The data were collected by interview, documentation, and observation. The results revealed that students who took part in the selection were classified based on their interests or skills through interviews and tests conducted by the selection team. However, the selection team experienced 2 obstacles: 1) time constraints during the selection process, 2) obstacles after the recruitment process. The first obstacle was when some students did not know what interests they have and the second one was when the members lost their motivation and commitment to learn. These obstacles affect other members and the learning process in the Arabic language student association. Therefore, the right recruitment process will attract more members that meet the qualifications and influence the student association. Then, in turn, it will make students more creative, explore themselves, become generation of achievers.
\end{abstract}

Keywords: $\quad$ recruitment, interests of Arabic learning, Arabic learning, Arabic language student association

\section{Introduction}

To attain learning objectives in an Arabic language student association, human resources are a very important factor. ${ }^{1}$ Therefore, the recruitment process plays an important role to get learning objectives. Management is also important in achieving a learning success. As stated by Fatkhurrohman, learning objectives will not be achieved

1 Jusuf Irianto, "Manajemen Sumber Daya Manusia Sektor Publik di Indonesia: Pengantar Pengembangan Model MSDM Sektor Publik", Jurnal Kebijakan dan Administrasi Publik, Vol. 24, 2011, 281-291. 
Arabiyât Jurnal Pendidikan Bahasa Arab dan Kebahasaaraban, 7 (2), 2020

if human resources, learning media, learning materials, and learning environments are not well planned. ${ }^{2}$

The process of recruitment of human resources is very important and can only be carried out through effective recruitment efforts. Therefore, there are some aspects of human resources that must be considered such as the mechanism of acceptance, professional guidance, career development and level of welfare. ${ }^{3}$ However, different circumstances if the human resources needed are to assist the learning process in an Arabic language student association. Therefore, this paper discusses the recruitment process in the association. The problem faced is unfamiliar between the recruitment of the employees in the work places and the recruitment of members of the Arabic language student association.

Jo Rick in his research stated that recruitment is any practice or activity carried out by an organization to attract potential human resources. ${ }^{4}$ Therefore, it is important to attention to the effectiveness of the recruitment process to get members who match the criteria. However, membership problems make the learning process in the Arabic language student association less optimal. Such as a lack of commitment to follow the learning process and members experience demotivation in learning Arabic. Therefore, solving the membership problem makes this discussion even more interesting to discuss by taking several precautionary measures during the membership recruitment process.

One obstacle in member management is the form and structure of social learning organizations that lead to bureaucratic or hierarchical organizations, which tend to treat their members as factors of production that are the same as other resource factors. ${ }^{5}$ Morgan in Magazine said that bureaucratic organizations tend to turn off creativity and innovation as well as the social spirit of members because all activities and actions always have to go through hierarchical procedures or on orders from superiors. ${ }^{6}$ A social student association must not lose its social principles in running a student association.

Membership in the Arabic language student association at the Maulana Malik Ibrahim State Islamic University, which is given the name "al-Kindy" is a sustainable membership. ${ }^{7}$ So every student who is accepted to be a member of the Arabic language student association has a moral responsibility to guide the younger members

2 Fathur Rohman, "Strategi Pengelolaan Komponen Pembelajaran Bahasa Arab", Arabiyat: Jurnal Pendidikan Bahasa Arab dan Kebahasaaraban, Vol. 1, No. 1, 2014.

${ }^{3}$ Jo Rick et al, "Systematic Techniques for Assisting Recruitment to Trials (START): Developing the Science of Recruitment", Trials, Vol. 14, No. S1, 2013.

${ }^{4}$ Jo Rick et al, "Systematic Techniques for Assisting Recruitment to Trials (START): Developing the Science of Recruitment".

${ }^{5}$ Yuslim \& Sugandi Luther Djumadi, "Pembinaan Sumber Daya Aparatur dalam Meningkatkan Pelayanan Publik di Kantor Camat Tenggarong Kabupaten Kutai Kartanegara (Studi Implementasi Peraturan Pemerintah No. 42 Tahun 2004)", Jurnal Administrative Reform, Vol. 1, No. 3, 2013.), 569-581. 2001).

${ }^{6}$ John M Ivancevich, Human Resource Management, (New York: Mc. Grow - Hill Companies,

${ }^{7}$ BSO al-Kindy, Guidance Book of Al-Kindy Arabic Language Community, 2018. 
Ara 6iyât Jurnal Pendidikan Bahasa Arab dan Kebahasaaraban, 7 (2), 2020

in the following years. As a result, it is very important to prepare well, manage the entire recruitment process of members of the Al-Kindy Arabic language student association for the effective learning process and the Arabic language environment.

What is meant by "interest" in this discussion is the specialization of the field in Arabic language skills. In accordance with the distribution of interest in Arabic language skills in various national level competition events held in Indonesia. ${ }^{8} \mathrm{Al}-$ Kindy student association has 6 division of specializations in Arabic language, such as; Arabic debate, Arabic speech, Arabic poetry, Arabic reading, Arabic singing, and Arabic calligraphy. ${ }^{9}$ It needs preparation and qualified selection team to carry out the interest-based recruitment. Human resource management must be appropriate, according to the needs of interests, and members of the selection team must be experts in the field of specialization in certain Arabic languages. Mondy and Noe stated that Human resource planning (HRP) is the process of systematically reviewing human resource requirements to ensure that the required numbers of employees, with the required skills are available when they are needed. ${ }^{10}$ This is in line with Mathis and Jakson, recruitment is a process that produces a number of qualified applicants for employment in a company or organization. ${ }^{11}$

The selection process is the end of the recruitment process to produce the human resources needed in the Arabic language student association. Siagian stated that selection is a variety of specific steps to decide which applicants will be accepted and which ones will be rejected. ${ }^{12}$ The selection process starts from the acceptance of the application and ends with a decision on the application. ${ }^{13}$ Therefore, the selection process determines the sustainability of learning and the Arabic la nguage environment in the al-Kindy student association.

Irham said the learning process in al-kindy experienced several problems occurred because of internal problems such as: lack of motivation in undergoing the learning process, different backgrounds of each member. ${ }^{14}$ Every problem can be taken as a precautionary measure, with a good and appropriate recruitment management process as needed. Therefore, this research is important to be discussed especially for the Al-Kindy Arabic language student association, hoping to prevent

8 Tim Penyusun, National Event Arabic Competition Guidebook, (Gebyar Khazanah Araby VIII UIN Maulana Malik Ibrahim Malang, 2019).

9 BSO al-Kindy, Guidance Book of al-Kindy Arabic Language Community, 2018.

10 Ellyta Yullyanti, "Analisis Proses Rekrutmen dan Seleksi pada Kinerja Pegawai di Sekretariat Jenderal Desdm dengan Metode SEM", Jurnal Ilmu Admninistrasi dan Organisasi, Vol. 16, No. 3, 2016, 131-39. 2001).

11 Jackson John H Robert I Mathis, Manajemen Sumber Daya Manusia, (Jakarta: Salemba Empat,

12 L'uba Tomáková, "The Effective Recruitment and Selection Practices of Organizations in the Financial Sector Operating in the Slovak Republic", Exclusive e-Journal, 2016, 1-7.

13 Bhasir Azhzhahiri, "Recruitment Analysis Through Open Bidding Announcement in the Selection of Prospective Echelon II", Bisnis \& Birokrasi: Jurnal Ilmu Administrasi dan Organisasi, Vol. 19, No. 3, 2013.

14 Interview with the chairman of al-Kindy, on March 15, 2020. 
Arabiyât Jurnal Pendidikan Bahasa Arab dan Kebahasaaraban, 7 (2), 2020

reducing the problems that occur due to the lack of credibility of the members due to inappropriate recruitment management processes.

The lack of interest and motivation to learn is one of the challenges in developing Arabic education. Muhbib stated that the factors that caused difficulties in learning Arabic were psychological, educational and social factors. ${ }^{15}$ This is based on the results of research by Jamsuri Muhammad Syamsuddin and Mahdi Mas'ud which shows that the causes of difficulties in learning Arabic are not entirely on the substance or material of the Arabic language, but on the lack of interest $(100 \%)$, the absence of Arabic language learning background (87\%), higher education material/curriculum (83\%), difficulty understanding Arabic material (57\%), and a nonconducive classroom environment. ${ }^{16}$

Based on the above problems, it is vital to explore the triumph recruitment process to produce members who are in accordance with the criteria of the Al-Kindy student association. However, during the last few years the recruitment process of the Al-Kindy student association has experienced several problems. Therefore, researchers intend to discuss the problems and provide solutions that are appropriate to the study of theory and research data collection. The expected outcome of this study was to get members of the Arabic language student association who meet the criteria. So, it is hoped that the learning process in the language student association will be effective.

Research on recruitment management has been carried out by many researchers, such as Ahmad Azmy, discussing Recruitment Strategies to Hire the Best People for Organization ${ }^{17}$ and Taru Skiekkinen, looking for Change and continuity in the academic profession: University of Finland as a living laboratory. ${ }^{18}$ They discussed recruitment and organizational management strategies to produce the best people in the organization. The recommended recruitment strategy is good, but needs to be used for recruitment in the field of Arabic learning. However, an accurate and specific studio level can be applied in the recruitment of Arabic learning fields. Then the Jiarakorn Hatariat, discussed the Development of the Recruitment and Selection Process for Teacher Assistants using Various Supports ${ }^{19}$ and Julie A. Luft discussed the Reconsidering Recruitment: Comprehensive and Strategic Recruitment from Secondary Science Teachers. ${ }^{20}$ They discussed the development of a recruitment

15 Asep Muhammad Saeful Islam, "Faktor Demotivasi Pembelajaran Bahasa Arab", Arabiyat: Jurnal Pendidikan Bahasa Arab dan Kebahasaaraban, Vol. 2, No. 1, 2015, 1-16.

16 Muhbib Abdul Wahab, Epistemologi dan Metodologi Pembelajaran Bahasa Arab, (Jakarta: Lembaga Penelitian UIN Syarif Hidayatullah, 2008).

17 Ahmad Azmy, "Recruitment Strategy to Hire The Best People for Organization", Journal of Management and Leadership, Vol. 1, No. 2, 2018, 1-16.

18 Taru Siekkinen, Elias Pekkola, and Teresa Carvalho, "Change and Continuity in the Academic Profession: Finnish Universities as Living Labs", Higher Education, Vol. 79, No. 3, 2020, 533-551.

19 Hatairat Jiarakorn, Siridej Suchiva, and Shotika Pasipol, "Development of Recruitment and Selection Process for Assistant Teachers Using Multiple Approaches", Procedia - Social and Behavioral Sciences, Vol. 191, 2015, 783-787.

20 Julie A. Luft, Sissy S. Wong, and Steve Semken, "Rethinking Recruitment: The Comprehensive and Strategic Recruitment of Secondary Science Teachers", Journal of Science Teacher Education, Vol. 22, No. 5, 2011, 459-474. 
Arabiyât Jurnal Pendidikan Bahasa Arab dan Kebahasaaraban, 7 (2), 2020

model using a variety of discussions. This research was specific and in accordance with the author's field of research, as well as research findings using both various findings in the recruitment process. Lastly, Sohel Ahmad, studying the importance of recruitment and selection process for sustainability of total quality management. Management literature discusses that selecting the right human resources can play an important role in the success of total quality management (TQM). The results of this study indicate that the selection of the right human resources has a significant effect on the effectiveness of quality management practices. $^{21}$

Based on previous research, the recruitment model is indicated using many approaches. The results of previous studies also revealed the importance of the suitability and effectiveness of the recruitment process to obtain human resources that meet the criteria. Several studies have discussed a lot about the recruitment process. However, case studies of recruitment management in the Arabic language student association have never been carried out. This article aims to explain the recruitment process in the al-Kindy Arabic language student association, and study the problems encountered in the recruitment process in the al-Kindy Arabic language student association. The implication of this research is the satisfaction of recruitment services, getting the best talent, and having superior competence in achieving learning targets in the Arabic language student association. Therefore, this research is important because its positive implications for the learning process of the Arabic language student association.

\section{Method}

This research used a descriptive qualitative approach and a case study method. Qualitative research aimed to reveal the members' recruitment management process in interest-based Arabic learning is implemented in the al-Kindy Arabic language student association that uses an interest system in learning Arabic, in certain natural contexts and using various scientific methods. ${ }^{22}$ The case study method in this research aimed to explore information about the recruitment management process and the interestbased selection process implemented in the al-Kindy Arabic language student association in the Arabic Language Student Association at Maulana Malik Ibrahim Malang State Islamic University. ${ }^{23}$

Data collection techniques were interview, observation and documentation. The researcher interviewed the selection team and the open recruitment coordinator. Observation was done to obtain information about the environment of the Arabic Language Student association and physical management of open recruitment. Meanwhile, documentation was used to obtain information about the open

21 Ahmad Sohel and Schroeder Roger G., "The Importance of Recruitment and Selection Process for Sustainability of Total Quality Management", International Journal of Quality \& Reliability Management, Vol. 19, No. 5, 2002, 540-550.

22 Lexy J Moleong, Metodologi Penelitian Kualitatif, (Bandung: PT Rosdakarya Offset, 2007).

23 Robeth K. Yin, Case Study Research Design and Methods: Third Edition, (USA: Sage Publication, 2002). 
Arabiyât Jurnal Pendidikan Bahasa Arab dan Kebahasaaraban, 7 (2), 2020

recruitment management and selection process of the document; specialization plan and selection handbook. The data analysis technique used in this study was carried out through the following steps: data collection, data reduction, data display, and verification and affirmative conclusions. ${ }^{24}$

\section{Result}

We conversed the results of this study in accord with the data we have got. According to Irham, the recruitment management of members of the al-Kindy Arabic language student association based on interest in learning Arabic was not done well before, resulting in members who did not meet the expectations and vision of the organization. ${ }^{25}$ This is an evaluation by al-Kindy advisers so that in the following year the recruitment process is expected to run better and in line with expectations.

Al-Kindy became a successful Arabic language student association in the Arabic language learning program because it had won many competitions at the national level. ${ }^{26}$ It is the one of the Arabic language communities under the auspices of Maulana Malik Ibrahim Malang State Islamic University, precisely in the Arabic Language Education Department ${ }^{27}$ to provide a student association forum where students who have an interest and talent in Arabic language proficiency are accommodated and can develop properly. When there are students who have interests and talents in Arabic and want to proceed in the al-Kindy Arabic language student association, the seniors will send them to participate in various Arabic competition events, the aim is to measure and know Arabic language skills, and also to increase motivation in learning Arabic. In accordance with the statement of Imam as a senior al-Kindy, participating in an important competition is important for al-Kindy members to measure the ability and motivation of learning Arabic, can also make our campus good. ${ }^{28}$ Evidenced by the existence of the al-Kindy student association, then created a good Arabic language environment, and achievers. In accordance with the jargon "al-Kindy: Mumtaz, student association achievers".

Although the al-Kindy student association was initially independent, and get not funding from the university for the learning process, with a good quality Arabic environment and proof of its achievements, in 2012 it managed to become a SemiAutonomous Body under the auspices of the Arabic Language Education Department of Maulana Malik Ibrahim State Islamic University Malang, with organizational details as follows:

\footnotetext{
${ }^{24}$ Burhan Bungin, Analisis Penelitian Kualitatif, (Jakarta: PT Raja Grafindo Persada, 2003).

25 Interview with the chairman of Al-kindy, on March 15, 2020.

26 Muhammad Bagus Ainun Muhammad Riki Sulthonul Fata and Khowarizmi Abdul Karim Najib, "Idarah Tarsyih A'dha Nadi al-Kindi fi Tathwir al-Kafaah al-Lughawiyah al-'Arabiyah", Jurnal Lisanudhad, Vol. 2, No. 2, 2018, 101-116.

27 BSO al-Kindy, Guidance Book of al-Kindy Arabic Language Community, 2018.

28 Interview with the mentor of al-Kindy, on March 16, 2020.
} 
Arabiyât Jurnal Pendidikan Bahasa Arab dan Kebahasaaraban, 7 (2), 2020

\section{Membership}

In al-Kindy Arabic language student association, there are several types of membership. ${ }^{29}$

\section{a. Caretaker}

They are included in the management group in the al-Kindy student association. They are the members who have gone through the learning process in Alkindy for at least one year. The first step is to choose the chairperson first, then the chairperson organizes the organizational structure of the board, namely chairman, secretary, treasurer, and management division. The management sector consists of interests and talents, humanitarian relations, networking, and routine training.

\section{b. Mentor}

After becoming a caretaker in the al-Kindy student association, they will automatically become a mentor in the following year. The task of the supervisor is to guide the management so that it is in accordance with the vision and mission of the student association. The supervisor also becomes a trainer in the process of learning Arabic in each of his activities.

\section{c. Member}

In the al-Kindy membership there are students who are members of ordinary people. So, all who pass the al-Kindy recruitment will become Al-kindy members, but in the process of organizational time, they will be divided into various groups. Like: Administrators, mentors, and members or students.

\section{Interest in Arabic Learning}

What is meant in the distribution of interests is the distribution of focus skills in the process of learning Arabic. Arabic language has 4 skills, such as: reading, writing, speaking, and listening. ${ }^{30}$ Some Arabic language skills are divided into several interests in learning Arabic, and used as a branch of the competition at the Arabic language event.

The division of interests in the al-Kindy Arabic language student association is 6: 1) Arabic speech, 2) Arabic poetry, 3) Arabic reading books, 4) Calligraphy, 5) Arabic debate, and 6) Arabic singing. At the beginning of the establishment of alKindy there was only interest in Arabic language debate skills, then as time went by and at the suggestion of the head of the Arabic Language Department then another interest in Arabic language skills was added.

Every element in al-Kindy depends on the human resources incorporated in al-Kindy, then referred to as members of the al-Kindy Arabic language student association. Therefore, the recruitment process of al-Kindy becomes an important point for the ongoing learning activities of Arabic and forms a good Arabic language environment. The al-Kindy recruitment process consists of several stages, 1) the

${ }^{29}$ Interview with the chairman of Al-kindy, on March 15, 2020.

30 Acep Hermawan, Metode Pembelajaran Bahasa Arab, (Bandung: PT Remaja Rosdakarya, 2014). 
Arabiyât Jurnal Pendidikan Bahasa Arab dan Kebahasaaraban, 7 (2), 2020

registration stage, 2) the Arabic language test stage, 3) the interview stage. ${ }^{31}$ The more detailed al-Kindy recruitment process is explained as follows:

\section{Registration stage}

At the registration stage, the management made a written announcement that the registration of members of the al-Kindy Arabic language student association had been opened with a predetermined time limit. The board also came to each class in the Arabic Education Department to make an oral announcement to the students to spread the information widely. Students who register are then recorded and processed to carry out the selection process in the next stage. However, every activity without good preparation will bring up an obstacle. One of the principles of management is preparation. ${ }^{32}$ Because of the lack of preparation from the recruitment committee, an error occurred when registering prospective participants, ${ }^{33}$ making the students who do not register as prospective participants can participate in the selection process because there are data errors. This is an evaluation material for the committee to always be careful in preparing for recruitment.

\section{Arabic language test stage}

The test is held after the participant registration is closed and the participant has confirmed the existence of this Arabic language test. The examiners of the Arabic language test stage are members of the selection team who have been divided according to their expertise and the Al-Kindy supervisor who has been appointed by the selection team to become examiners. ${ }^{34}$ The selection test place at this stage is located outside the classroom or in an open place, with the aim that the examiners and selection participants are not stressed by the conditions and situations of the Arabic language test.

Technical at this stage are examiners who have been appointed by the selection team to the test place according to the examiner's desires, then participants come to examiners who have been determined by the selection team. The exam material on Arabic tests is adjusted to the background of the test taker's abilities and is adjusted to the examiner's agreement and the selection team. The material was tested in the form of Arabic speaking skills, listening skills and then translating Arabic into Indonesian.

\section{Interview test stage}

The interview stage is carried out in conjunction with the Arabic language test stage. Because of the importance at this stage of the interview test, the interviewer of the interview stage is the al-Kindy advisor who has been appointed by the selection team as the interviewer. The interview was held outside the classroom or in an open

31 Interview with the chairman of al-Kindy, on March 15, 2020.

32 Mohammad Thoha, "Pembelajaran Bahasa Arab Dengan Pendekatan Manajemen Berbasis Sekolah", Pembelajaran Bahasa Arab, Vol. 6, No. 1, 2012, 12.

33 Interview with the chairman of al-Kindy, on March 15, 2020.

34 Interview with the chairman of al-Kindy, on March 15, 2020. 
Arabiyât Jurnal Pendidikan Bahasa Arab dan Kebahasaaraban, 7 (2), 2020

space, so that test takers are not stressed and comfortable when asked by the interviewer.

Technically the interview stage is not much different from the Arabic language test where the interviewer looks for a place in accordance with his wishes then the participants come to the interviewer. However, participants may not take the interview stage before carrying out the Arabic language test, and be guided by the selection team. The material being tested is the question of commitment to take part in alKindy activities, so sometimes at this stage it is also called a commitment test. At this stage the interviewer gives a score based on the test taker's commitment to attend the al-Kindy program and to follow the process of learning Arabic in al-Kindy. After this stage is completed, the results of the interview test results are collected to the selection team to determine whether or not the al-Kindy membership selection participant has passed.

\section{Discussion}

The recruitment process arises by considering plans for human resource needs such as considering the number and type of vacant positions that must be filled, when these positions must be filled, what personnel resources or expertise are needed to fill these positions. ${ }^{35}$ After it carries these considerations out, we continue the determination of recruitment strategies and methods. ${ }^{36}$ Under the statement related to recruitment according to Mathis and Jakson, recruitment is a process that produces several qualified applicants for employment in a company or organization. ${ }^{37}$ Therefore, good management is needed to prepare the recruitment process so that the recruitment process runs as expected. In the context of education, management is defined as a collaborative activity of a group of people who are members of an educational organization to achieve educational goals that have been predetermined to be effective and efficient. ${ }^{38}$

In the al-Kindy recruitment process, there are several technical conclusions that can be drawn. The al-Kindy Recruitment process has a source of certain applicants or certain regions, namely Arabic language students. Therefore, the recruitment process used special methods that are appropriate to the environment and circumstances of students. The characteristics of different prospective recruitment participants are based on the backgrounds of students from different schools, thus requiring good preparation and appropriate budget planning in order to achieve organizational goals. In obtaining qualified personnel, various stages of human

35 Isaac Christopher Otoo, Juliet Assuming, and Paul Mensah Agyei, "Effectiveness of Recruitment and Selection Practices in Public Sector Higher Education Institutions: Evidence from Ghana", European Scientific Journal, Vol. 14, No. 13, 2018, 199. 2013).

36 Wukir, Manajemen Sumber Daya Manusia Dalam Organisasi Sekolah, (Yogyakarta: Multi Presindo, 2001).

37 Jackson John H Robert I Mathis, Manajemen Sumber Daya Manusia, (Jakarta: Salemba Empat,

${ }^{38}$ Lia Yuliana Suharsimi Arikunto, Manajemen Pendidikan, (Yogyakarta: Aditya Media, 2008), 290. 
resource management activities are needed. In the initial stage, human resource management starts at the recruitment stage which can produce qualified candidates. ${ }^{39}$

If the recruitment process in al-Kindy is examined in a theory, then the opinion theory from Dunnette is appropriate, namely: independent variable in the recruitment theory. ${ }^{40}$ This variable is divided into 3 elements, namely: recruiter, source recruitment, and administrative policies and procedures. ${ }^{41}$ The use of methods that are adapted to environmental conditions and adjust to the circumstances of students is a recruitment source. Student characteristics, impressions, and motivation of students to join and participate in the recruitment of al-Kindy membership is a recruiter. Steps, administration, and funding in the recruitment process are administrative policies and procedures.

Based on the theoretical framework, there are recruitment variables having seven indicators namely organizational policy, recruitment planning, recruitment methods, procedures, implementation time, recruitment sources, and recruitment constraints. $^{42}$ After going through the factor confirmation test on the seven recruitment indicators, it turns out there is one indicator that needs to be further discussed, namely in the recruitment constraints. The steps taken are giving suggestions for improving the concept of recruitment in accordance with existing theories, so that the recruitment process goes well and in line with expectations.

The steps in the recruitment process of the Arabic language student association al-Kindy, according to the theories presented by researchers are: 1) planning, 2) introduction of the organization, 3) test implementation, 4) results. The four steps are more detailed as follows:

\section{Planning}

In planning this is influenced by the integrity of the organization or selection team. And in this case, the team leader as the holder of the ongoing recruitment process must be able to manage it well. According to Edwards Deming that a good leader is not only smart; he must have balance between the emotional and logical side to run every process in the recruitment properly. ${ }^{43}$ There are no more obstacles occur, like not joining the recruitment but taking the selection test process. ${ }^{44}$ With the integrity of the team and the good leadership coordinator, such problems can be overcome and not happen again the following year.

39 Ian Davison, Chris McManus, and Celia Brown, "Factors Affecting Recruitment into General Practice: A Double Binary Choice Approach", Advances in Health Sciences Education, Vol. 25, 2019.

40 Independent variable is a set of rules, procedures, and decision decisions that are considered as part of organizational recruitment.

41 M.D. Dunnette \& L.M. Hough, Handbook of Industrial and Organizational Psychology, (Mumbai: Jaico Publishing House. Vol. 2. (2nd ed.), 1998), 520.

42 Patricia Kingdon, "The Cosmopolitan Engineering Student: An Analysis of a Recruitment Campaign for KTH Royal Institute of Technology in Stockholm ", International Journal of Technology and Design Education, Vol. 28, No. 3, 2018, 787-802.

43 W. Edwards Deming, The New Economics for Industry, Government, Education, (Cambridge: Center of Advance Educational Service, 1994).

44 Interview with the chairman of Al-kindy, on March 15, 2020. 
Arabiyât Jurnal Pendidikan Bahasa Arab dan Kebahasaaraban, 7 (2), 2020

This plan also includes suitability between the budget issued by the organization, interests or interest classes of applicants who will be recruited to become members based on their skills, carried out on the basis of analysis, and have gone through comprehensive planning. ${ }^{45}$ This will affect to get applicants with the specified qualifications. In addition, the things that need to be prepared in this stage are: determining the source of applicants so that they can determine the appropriate test method, determining the selection team and interviewer criteria so that the recruiter matches the needs and qualifications of the test, and do not forget to determine the criteria for prospective members to be recruited. ${ }^{46}$

In accordance with Teguh Sriwidadi's statement, an organization will develop its level of trust if it can operate efficiently, cost-effectively, avoiding waste and reworking, which is expected to create service satisfaction. ${ }^{47}$ Therefore, teamwork is very necessary in the success of the recruitment process.

\section{Introduction to Organizations}

In this case, what is meant is an introduction to organizational culture, organizational vision and mission, and all matters related to Al-Kindy organizations. In order to achieve the recruitment goal, the selection team should use the person organization approach. ${ }^{48}$ To achieve the person organization approach, it is also necessary to deliver an organization culture. There are four reasons 4 why the delivery of organizational culture is very important in the recruitment process: 1) it is important for applicants to know the values, norms, and beliefs that underlie the organization. 2) work is more directed to the requirements, by knowing the organization's vision and mission. 3) applicants and organizations get an exchange of information about values and assumptions in organizational culture. This is done to make applicants and organizations have better assumptions and values. 4) the delivery of a culture of organizational performance is to achieve the goals of the person organization approach. ${ }^{49}$ With the achievement of the person organization approach will affect the performance results later.

By knowing the culture of the organization, it will reduce the obstacles such as participants' resign and no participation in teaching and learning activities in al-Kindy and also the learning motivation constraints that descended. ${ }^{50}$ Motivation is important in learning languages. Motivation has a contribution in fostering students' interest in

45 Julie A. Luft, Sissy S. Wong, and Steve Semken, "Rethinking Recruitment: The Comprehensive and Strategic Recruitment of Secondary Science Teachers", 459-474.

46 Fiona Patterson and others, "Evaluation of Two Selection Tests for Recruitment into Radiology Specialty Training", BMC Medical Education, Vol. 16, No. 1, 2016, 1-10.

47 Teguh Sriwidadi, "Manajemen Mutu Terpadu", The Winners, Vol. 2, 1998, 107-15.

48 Patricia Kingdon, "Correction to: The Cosmopolitan Engineering Student: An Analysis of a Recruitment Campaign for KTH Royal Institute of Technology in Stockholm ", International Journal of Technology and Design Education, Vol. 28, No. 3, 2018, 787-802.

49 Patricia Kingdon, "Correction to: The Cosmopolitan Engineering Student: An Analysis of a Recruitment Campaign for KTH Royal Institute of Technology in Stockholm ", 782-802.

50 Interview with the chairman of al-Kindy, on March 15, 2020. 
Arabiyât Jurnal Pendidikan Bahasa Arab dan Kebahasaaraban, 7 (2), 2020

learning a language. ${ }^{51}$ Submission of culture is indeed necessary in order to form a match between applicants and organizations that greatly affect the effect of performance, commitment, desire to quit, and motivation of prospective members or applicants.

\section{Test Implementation}

This process is included in the selection process, all predetermined criteria will be tested at this stage. Selection is the process of gathering and evaluating current and accurate information about individuals who will become members. ${ }^{52}$ The selection process is the end of the recruitment process to produce the human resources needed in the Arabic language student association. Furthermore Siagian stated that selection is a variety of specific steps taken to decide which applicants will be accepted and which applicants will be rejected. The selection process starts from the acceptance of the application and ends with a decision on the application. ${ }^{53}$ Therefore, the selection process determines the sustainability of learning and the Arabic language environment in the Al-Kindy student association.

What's interesting in this test process is, applicants must be classified based on interests. Therefore it requires 3 test stages, namely: 1) the registration stage, 2) the Arabic language test stage, 3 ) the interview stage. ${ }^{54}$ and everything has been explained above stages. However, there are obstacles when applicants do not know what interests they have. Therefore, it takes an interest ability test and is adjusted to the interview test data to find out the applicant's Arabic language background. Because differences in the characteristics of each individual related to the educational background of students is one of the problems that is often faced in learning. ${ }^{55}$ The process of selecting new members is considered to be one of the causes of the diversity of the quality of members in Al-kindy. Existing selection is less able to classify interests so that commitment and learning motivation of members is reduced.

\section{Results}

When running all the selection procedures properly, it will produce applicants who pass the selection or said to be new members of al-Kindy in accordance with the criteria and qualifications. In the process, al-Kindy also recruits members with recommendations from the supervisor. Evidently, the members recommended by the supervisor also prove good achievements. ${ }^{56}$ As for al-Kindy, when expecting new

51 Muhammad Bagus Ainun Muhammad Riki Sulthonul Fata and Khowarizmi Abdul Karim Najib, "Idarah Tarsyih A'dha Nadi al-Kindi fi Tathwir al-Kafaah al-Lughawiyah al-'Arabiyah", 101-116.

52 Laura McEwen-Smith and others, "National Recruitment Scheme for Pre-Registration Pharmacist Training in England and Wales: A Mixed Method Evaluation of Experiences of Applicant Pharmacy Students", BMC Medical Education, Vol. 19, No. 1, 2019, 1-10.

53 K. A. Rahman, 'Rekrutmen Tenaga Pendidik dalam Peningkatan Mutu Madrasah Aliyah Negeri Insan Cendekia Jambi', Nadwa, Vol. 9, No. 1, 2015, 23-38.

${ }^{54}$ Interview with the chairman of Al-kindy, on March 15, 2020.

55 Agung Setiyawan, "Problematika Keragaman Latar Belakang Pendidikan Mahasiswa dan Kebijakan Program Pembelajaran Bahasa Arab", Arabiyat: Jurnal Pendidikan Bahasa Arab dan Kebahasaaraban, Vol. 5, No. 2, 2018, 195-213.

56 Interview with the mentor of al-Kindy, on March 16, 2020. 
Arabiyât Jurnal Pendidikan Bahasa Arab dan Kebahasaaraban, 7 (2), 2020

members who are highly committed, have clear interests and focus, the learning of Arabic in the al-Kindy student association will run well and smoothly.

\section{Conclusion}

There are many studies and research related to the recruitment process. They conducted the research to develop the quality of the existing recruitment process. As in this study, researchers are attempting to improve the quality of the recruitment process in the "al-Kindy" Arabic language student association. This is done so that the recruitment process produces members who are highly committed, have evident interests and focus. So that running the Arabic language teaching and learning activities in al-Kindy goes according to expectations and produces a generation of achievers under the jargon of al-Kindy "mumtaz student association achievers".

The steps in the recruitment process of the Al-kindy Arabic language student association are: 1) Planning: this process becomes important because if at this stage it goes poorly, it will have terrible consequences at a later stage. 2) Organizational introduction: based on the supervisory management function and the existing recruitment method, this stage is proposed by the researcher to be carried out in the next recruitment process. This stage is important to find out the compatibility between the organization and the applicant, the suitability of the vision and mission between the organization and the applicant, so that when the applicant qualifies to become a member, there will be no misunderstanding and lead to decreased interest and commitment of members. 3) Implementation of the test: in this process can be called the selection process which is divided into 3 stages: the registration stage, the Arabic language test stage, and the interview stage. The stage is the core stage in the recruitment process. 4) Outcome: After going through various processes, it will produce applicants who pass the selection so they will be awarded the extra members of the Arabic al-Kindy student association.

This research is only a design of the process of recruitment of the Arabic language student association al-Kindy based on interest. And according to the existing recruitment method, then produced several proposals for the good of the next alKindy recruitment process, so we expect it that the teaching and learning process can run well. Researchers hope there will be further research to complete and continue the research that we have compiled. For your criticism and suggestions in writing our research, thank you.]

\section{REFERENCES}

Abdul Wahab, Muhbib. Epistemologi dan Metodologi Pembelajaran Bahasa Arab. Jakarta: Lembaga Penelitian UIN Syarif Hidayatullah, 2008.

Arikunto, Suharsimi., \& Lia Yuliana. Manajemen Pendidikan. Yogyakarta: Aditya Media, 2008. 
Arabiyât Jurnal Pendidikan Bahasa Arab dan Kebahasaaraban, 7 (2), 2020

Azhzhahiri, Bhasir. "Recruitment Analysis Through Open Bidding Announcement in the Selection of Prospective Echelon II", Bisnis \& Birokrasi: Jurnal Ilmu Administrasi dan Organisasi, Vol. 19, No. 3, 2013.

Azmy, Ahmad. "Recruitment Strategy to Hire The Best People for Organization", Journal of Management and Leadership, Vol. 1, No. 2, 2018.

Bungin, Burhan. Analisis Penelitian Kualitatif. Jakarta: PT Raja Grafindo Persada, 2003.

Davison, Ian., Chris McManus, and Celia Brown. "Factors Affecting Recruitment into General Practice: A Double Binary Choice Approach", Advances in Health Sciences Education, Vol. 25, 2019.

Deming, W. Edwards. The New Economics for Industry, Government, Education. Cambridge: Center of Advance Educational Service, 1994.

Djumadi, Yuslim., \& Sugandi Luther. "Pembinaan Sumber Daya Aparatur dalam Meningkatkan Pelayanan Publik Di Kantor Camat Tenggarong Kabupaten Kutai Kartanegara (Studi Implementasi Peraturan Pemerintah No. 42 Tahun 2004)", Jurnal Administrative Reform, Vol. 1, No. 3, 2013.

Dunnette, M.D., \& L.M. Hough. Handbook of Industrial and Organizational Psychology. Mumbai: Jaico Publishing House. Vol. 2. (2nd ed.), 1998.

Hermawan, Acep. Metode Pembelajaran Bahasa Arab. Bandung: PT Remaja Rosdakarya, 2014.

Irianto, Jusuf. "Manajemen Sumber Daya Manusia Sektor Publik di Indonesia: Pengantar Pengembangan Model MSDM Sektor Publik", Jurnal Kebijakan dan Administrasi Publik, Vol. 24, 2011.

Islam, Asep Muhammad Saepul. "Faktor Demotivasi Pembelajaran Bahasa Arab", Arabiyat: Jurnal Pendidikan Bahasa Arab dan Kebahasaaraban, Vol. 2, No. 1, 2015.

Ivancevich, John M. Human Resource Management. New York: Mc. Grow - Hill Companies, 2001.

Jiarakorn, Hatairat., Siridej Suchiva, and Shotika Pasipol. "Development of Recruitment and Selection Process for Assistant Teachers Using Multiple Approaches", Procedia - Social and Behavioral Sciences, Vol. 191, 2015.

al-Kindy, BSO. Guidance Book of al-Kindy Arabic Language Community, 2018.

Kingdon, Patricia. "Correction to: The Cosmopolitan Engineering Student: An Analysis of a Recruitment Campaign for KTH Royal Institute of Technology in Stockholm", International Journal of Technology and Design Education, Vol. 28, No. 3, 2018.

Luft, Julie A., Sissy S. Wong, and Steve Semken. "Rethinking Recruitment: The Comprehensive and Strategic Recruitment of Secondary Science Teachers", Journal of Science Teacher Education, Vol. 22, No. 5, 2011.

Mathis, Robert I., \& John H Jackson. Manajemen Sumber Daya Manusia. Jakarta: Salemba Empat, 2001. 
Arabiyât Jurnal Pendidikan Bahasa Arab dan Kebahasaaraban, 7 (2), 2020

McEwen-Smith, Laura., Malcolm James Price, Gail Fleming, Tim Swanwick, Christine Hirsch, Asma Yahyouche, and others. "National Recruitment Scheme for PreRegistration Pharmacist Training in England and Wales: A Mixed Method Evaluation of Experiences of Applicant Pharmacy Students", BMC Medical Education, Vol. 19, No. 1, 2019.

Moleong, Lexy J. Metodologi Penelitian Kualitatif. Bandung: PT Rosdakarya Offset, 2007.

Muhammad Riki Sulthonul Fata, Muhammad Bagus Ainun, and Khowarizmi Abdul Karim Najib, "Idarah Tarsyih A'dha Nadi al-Kindi fi Tathwir al-Kafaah alLughawiyah al-'Arabiyah", Jurnal Lisanudhad, Vol. 2, No. 2, 2018.

Otoo, Isaac Christopher., Juliet Assuming, and Paul Mensah Agyei. "Effectiveness of Recruitment and Selection Practices in Public Sector Higher Education Institutions: Evidence from Ghana", European Scientific Journal, Vol. 14, No. 13, 2018.

Patterson, Fiona., Alec Knight, Liam McKnight, and Thomas C. Booth. "Evaluation of Two Selection Tests for Recruitment into Radiology Specialty Training", BMC Medical Education, Vol. 16, No. 1, 2016.

Rahman, K. A. "Rekrutmen Tenaga Pendidik Dalam Peningkatan Mutu Madrasah Aliyah Negeri Insan Cendekia Jambi", Nadwa, Vol. 9, No. 1, 2015.

Rick, Jo., Peter Bower, David Collier, Sandra Eldridge, Jonathan Graffy, Anne Kennedy, and others. "Systematic Techniques for Assisting Recruitment to Trials (START): Developing the Science of Recruitment", Trials, Vol. 14, No. S1, 2013.

Rohman, Fathur. "Strategi Pengelolaan Komponen Pembelajaran Bahasa Arab", Arabiyat: Jurnal Pendidikan Bahasa Arab dan Kebahasaaraban, Vol. 1, No. 1, 2014.

Setiyawan, Agung. "Problematika Keragaman Latar Belakang Pendidikan Mahasiswa dan Kebijakan Program Pembelajaran Bahasa Arab", Vol. 5, No. 2, 2018.

Siekkinen, Taru., Elias Pekkola, and Teresa Carvalho. "Change and Continuity in the Academic Profession: Finnish Universities as Living Labs", Higher Education, Vol. 79, No. 3, 2020.

Sohel, Ahmad., and Roger G. Schroeder. "The Importance of Recruitment and Selection Process for Sustainability of Total Quality Management", International Journal of Quality \& Reliability Management, Vol. 19, No. 5, 2002.

Sriwidadi, Teguh. "Manajemen Mutu Terpadu", The Winners, Vol. 2, 1998.

Thoha, Mohammad. "Pembelajaran Bahasa Arab dengan Pendekatan Manajemen Berbasis Sekolah", Pembelajaran Bahasa Arab, Vol. 6, No. 1, 2012.

Tim Penyusun, National Event Arabic Competition Guidebook (Gebyar Khazanah Aroby VIII UIN Maulana Malik Ibrahim Malang, 2019)

Tomčíková, L’uba. "The Effective Recruitment and Selection Practices of Organizations in the Financial Sector Operating in the Slovak Republic", Exclusive e-Journal, 2016. 
Arabiyât Jurnal Pendidikan Bahasa Arab dan Kebahasaaraban, 7 (2), 2020

Wukir. Manajemen Sumber Daya Manusia dalam Organisasi Sekolah. Yogyakarta: Multi Presindo, 2013.

Yin, Robeth K. Case Study Research Design and Methods: Third Edition. USA: Sage Publication, 2002.

Yullyanti, Ellyta. "Analisis Proses Rekrutmen dan Seleksi Pada Kinerja Pegawai di Sekretariat Jenderal DESDM dengan Metode SEM", Jurnal Ilmu Admninistrasi Dan Organisasi, Vol. 16, No. 3, 2016. 